\author{
Asian Economic and Financial Review \\ $\operatorname{ISSN}(e): \quad 2222-6737$ \\ $\operatorname{ISSN}(p): \quad 2305-2147$ \\ DOI: 10.18488/journal.aefr.2021.115.406.417 \\ Vol. 11, No. 5, 406-417. \\ (C) 2021 AESS Publications. All Rights Reserved. \\ URL: www.aessweb.com \\ check for
}

\title{
ASYMMETRIC IMPACT OF EXCHANGE RATE FLUCTUATIONS ON MONEY DEMAND IN SUDAN
}

\author{
Tomader Elhassan \\ Jouf University, Department of Administrative Sciences and Humanities, \\ Qurayyat, Saudi Arabia. \\ Email:tomadurgaber@gmail.com Tel:+966531039087
}

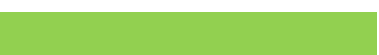

\begin{abstract}
This study aims to examine the asymmetric impact of exchange rate fluctuations on money demand in Sudan. The non-linear autoregressive distributed lag (ARDL) model was applied to data pertaining to 1960-2018. The empirical results suggest that the impact of the exchange rate is asymmetric in the long and short terms. In the short term, a positive change in the exchange rate increases money demand, while a negative change in the exchange rate has no effect. However, in the long term, a positive change in the exchange rate increases money demand, and a negative change has the same effect. In the long term, a negative change in the exchange rate has a greater effect than a positive change, indicating that a depreciation of the Sudanese pound has a greater effect. The difference between the positive and negative changes in the exchange rate indicates its asymmetric effect on money demand in Sudan. This study recommends that monetary policy in Sudan should target such positive and negative changes in the exchange rate, and that decision makers should adopt policies that achieve exchange rate stability. In addition, policymakers should also aim to establish an industrial production base to reduce reliance on imports.
\end{abstract}

Article History

Received: 9 February 2021

Revised: 12 March 2021

Accepted: 14 April 2021

Published: 6 May 2021

Keywords

Money demand

Exchange rate

Asymmetric impact

Non-linear ARDI

Sudan.

JEL Classification:

E41; F31

Contribution/Originality: This study contributes to the existing literature on Sudan. This study uses the new estimation methodology of the non-linear autoregressive distributed lag (ARDL) model. This paper contributes the first logical analysis of the asymmetric impact of exchange rate fluctuations on money demand in Sudan.

\section{INTRODUCTION}

The stability of the money demand function has been deemed essential for the formulation and implementation of an effective monetary policy. With an unstable money demand function, policies are ineffective (Bhatta, 2013). Previously, money demand was measured by income and interest rate. However, exchange rates play an important role in an economy, particularly in emerging economies and are crucial to the success of economic reform programmes. Economic liberalisation policies have pursued low inflation rates and structural adjustment of economic sectors. Mundell (1963) first predicted that money demand depends on the exchange rate in addition to income and interest rates. Arango \& Nadiri (1981) argued that an appreciation of foreign currency increased the value, in local currency terms, of foreign assets held by domestic residents. If this increase led to consumption growth, along with an increase in wealth, then money demand could also increase. Bahmani-Oskooee \& Pourheydarian (1990) argued that if further appreciation of foreign currency were expected, demand for foreign currency from domestic residents would increase. Hence, the exchange rate seems to be related to the money demand function through the wealth effect or the substitution effect. 
Some scholars have clarified the impact of exchange rate on money demand (Arango \& Nadiri, 1981; BahmaniOskooee \& Malixi, 1991; Bahmani-Oskooee, Xi, \& Wang, 2012; Domowitz \& Elbadawi, 1987; Ebaidalla, 2016; Harb, 2004; Karfakis, 1991; Marquez, 1987; Mundell, 1963; Suliman \& Dafaalla, 2011).

Recent studies have also examined the asymmetric effect of exchange rate on money demand (Alsamara \& Mrabet, 2019; Bahmani-Oskooee \& Baek, 2016; Bahmani-Oskooee \& Gelan, 2019; Bahmani-Oskooee \& Baek, 2017; Haider, Ganaie, \& Kamaiah, 2017; Leong, Puah, \& Liew, 2018; Mahmood \& Alkhateeb, 2018). These previous studies have used the autoregressive distributed lag (ARDL) approach among other estimation methods (Arango \& Nadiri, 1981; Bahmani-Oskooee \& Malixi, 1991; Bhatta, 2013; Domowitz \& Elbadawi, 1987; Ebaidalla, 2016; Marquez, 1987; Mundell, 1963; Nwude, Offor, \& Offor, 2018; Suliman \& Dafaalla, 2011).

The Sudanese economy had no industrial production base and therefore depended on imports to satisfy the needs of domestic consumption. This dependence on imports led to a demand for more foreign currency causing greater instability in the exchange rate. For Sudan, the local currency was neither a store of value nor a medium of exchange in high-value transactions, and has been replaced by the dollar or euro. However, consumer spending was greater than investment spending, characterised by a remarkable increase in the value of imports relative to exports. Such factors have negatively affected the real national income and thus the money demand function.

Sudan has adopted different exchange rate regimes (fixed, floating, and dual exchange rate) over the last 70 years. A fixed exchange rate regime was adopted from 1956 to 1979, but by the end of 1979, it had changed to a flexible exchange rate regime. Since then, the exchange rate has experienced sustained devaluations and interventions. These changes in the exchange rate were accompanied by large fluctuations in the macroeconomic indicators (Ebaidalla, 2016). In the 1980s, the exchange rate experienced repeated devaluations due to economic and political instability, and in 1992 Sudan adopted a floating exchange rate regime. However, in October 1993, this was replaced by the dual exchange rate. After 1995, the exchange rate stabilised due to inflows of foreign direct investment and oil revenues. From 2008 to 2018 , the exchange rate witnessed a sharp decline due to the global financial crisis, and the economy experienced a decrease in the inflow of foreign currency. In 2011, stalled oil revenues presented several economic challenges, and as a result, the exchange rate deteriorated (Ebaidalla, 2016). Some scholars examined the symmetric and asymmetric effects of the exchange rate on other economic variables (Arabi, 2012; Ebaidalla, 2014; Mahmood \& Alkhateeb, 2018). In addition, researchers in Sudan have studied the relationship between the exchange rate and the demand for money using different estimation methods (e.g., the error-correction model and the structure vector autoregressive technique) for a shorter period. However, the effects of exchange rate fluctuation on money demand in Sudan are yet to be examined.

Sudan's economy presents an interesting case study, with its heavy dependence on imports, which has reduced its foreign exchange reserves drastically. This has affected the exchange rate and the legitimacy of the Sudanese pound. Most studies on the exchange rate in Sudan have focused on its determinants and fluctuations. Since foreign exchange reserves in Sudan have sharply declined, understanding the positive and negative impacts of exchange rate fluctuations on money demand would help in adopting sound monetary policies. In addition, this study adds new knowledge to African and international studies by providing a better understanding of the positive and negative effects of exchange rate fluctuations on money demand. This study examines the period from 1960 to 2018 since the most important economic fluctuations in Sudan occurred during this time. Data was collected from the Central Bank of Sudan, and the non-linear ARDL approach was applied to ascertain the asymmetric impact of the exchange rate on money demand. This study brings forth a much-needed discussion on how exchange rate fluctuations have had varying effects on money demand in Sudan. It will therefore be of immense interest to the economic policymakers, and economic scholars will also benefit from reading this article.

The remainder of this paper is organised as follows: Section 2 presents the literature review; section 3 presents the model and resources as well as the data and methodology; section 4 discusses the main findings and provides analysis and assessment; and section 5 presents the conclusions, recommendations, and limitations. 


\section{LITERATURE REVIEW}

Studies have examined the determinants of money demand and found the exchange rate to be a significant variable. However, these studies did not discuss the positive and negative effects of exchange rate fluctuations on money demand, but some studies have discussed positive and negative exchange rate fluctuations associated with macroeconomic variables. Leong, Puah, Lau, \& Shazali (2019) used the non-linear ARDL approach on quarterly data from 1991 to 2018 in Malaysia. They found asymmetric impacts between exchange rate appreciation and consumption in the short term. They also noted an asymmetric relation between the exchange rate and money demand in the long term. Alsamara \& Mrabet (2019) used quarterly data from 1986 to 2014 in Turkey and employed the non-linear ARDL approach. They found that the effect of a negative shock on the exchange rate (appreciation) was stronger than the effect of a positive shock (depreciation) on money demand.

Bahmani-Oskooee \& Gelan (2019) employed the non-linear ARDL approach to study 18 African economies. They found that changes in exchange rates have asymmetrical short-run effects on money demand. However, only a limited number of African countries could transform asymmetrical effects in the short term into the long term. Bahmani-Oskooee et al. (2019) applied the NARDL method to data from emerging countries (India, Indonesia, Korea, the Philippines, and Singapore) and demonstrated that exchange rate changes asymmetrically affected money demand in the long and short terms. Aworinde \& Akintoye (2019) used the linear and non-linear ARDL methods. They employed quarterly data from 1960 to 2017 in Nigeria and found that exchange rate volatility had an asymmetric impact on money demand in the short and long terms in Nigeria. When nonlinearity was introduced, the money demand was stable. Mahmood \& Alkhateeb (2018) used annual data from 1968 to 2016 in Saudi Arabia and employed the NARDL approach. Their results revealed that real appreciation in the US dollar had a positive effect on money demand, but real depreciation had a negative effect. Nwude et al. (2018) used the vector error correction test and employed quarterly data from 1993 to 2012 in Nigeria. They found that the interest rate and exchange rate volatility did not significantly affect money demand in developing countries. They also found that in developing economies, the money demand function was unstable. Nyumuah (2018) applied the error correction model estimations from Q2 1993 to Q4 2012 in the African countries of Equatorial Guinea, the Gambia, Nigeria, and Uganda and found that the interest rate and exchange rate volatility had little effect on money demand in developing countries. The money demand function in their study was also found to be unstable. Haider et al. (2017) adopted the NARDL approach to examine the period from April 2004 to November 2015 in India and found that the rupee's appreciation and depreciation had asymmetric effects on money demand in the short and long terms.

Bahmani-Oskooee \& Baek (2017) employed the linear and non-linear ARDL approaches and used data from Q3 1973 to Q3 2014 in Korea. They demonstrated that the effect of exchange rate was asymmetric in the short term, and the effect was statistically and significantly positive. Furthermore, the effect was statistically and significantly negative. In the long term, the positive and negative effects of exchange rate fluctuations had a positive sign, but the difference in the size of the elasticities indicated an asymmetric effect of the exchange rate. Bahmani-Oskooee \& Baek (2016) employed the NARDL approach to estimate quarterly data from 1973 to 2014 in Japan and found that exchange rate fluctuations had asymmetric effects in the long term. Ebaidalla (2016) employed the structure vector autoregressive technique to estimate annual data from 1979 to 2010 in Sudan and found that real demand shocks were important in explaining the real exchange rate fluctuations. In contrast, supply and nominal shocks had little effect on the real exchange rate. Suliman \& Dafaalla (2011) applied the error correction model to estimate data from 1960 to 2010 in Sudan and demonstrated that the money demand function was stable. Domowitz \& Elbadawi (1987) applied the dynamic error-correction model from 1956 to 1982 in Sudan and found that the money demand function was stable, and that exchange rate affected money demand. In general, most previous literature indicates varied impacts of exchange rate fluctuations on money demand. Although previous studies have utilised various estimation methods (e.g., the error correction model and the structural vector autoregressive technique), the asymmetric effects of exchange rate fluctuations on money demand in Sudan have yet to be examined with the 
NARDL approach. This study utilized information from previous studies to develop a design with appropriate variables and estimation methods, with the aim of bridging this gap in Sudanese literature. In addition, the current study helps to mitigate the shortage of NARDL studies on African countries concerning the critical role of exchange rate on their economies.

\section{METHODS}

3.1. Data Sources

This study employed the annual time series data of real money demand (LM), real gross domestic product (LGDP), nominal exchange rate (LEX), and inflation (LINF). Data were collected from the Central Bank of Sudan (CBS, 2019) for the period between 1960 and 2018.

\subsection{Model Specification}

Based on Mundell's (1963) prediction and the literature reviews by Arango \& Nadiri (1981); Domowitz \& Elbadawi (1987); Marquez (1987); Bahmani-Oskooee \& Malixi (1991); Karfakis (1991); Bahmani-Oskooee et al. (2012); Bahmani-Oskooee \& Baek (2017); Harb (2004); Leong et al. (2019); Alsamara \& Mrabet (2019); Mahmood \& Alkhateeb (2018) and Haider et al. (2017), the model was defined as follows:

\section{$L M=f(L G D P, L E X, L I N F)$}

Where, LM is the logarithm of real money demand, LGDP is the logarithm of real gross domestic product, LEX is the logarithm of nominal exchange rate (US dollar per Sudanese currency), and LINF is the logarithm of the consumer price index. The expected signals for the variables are a positive sign for LGDP and a negative sign for LINF. The exchange rate sign can be negative or positive depending on the wealth effect or currency substitution effect (Haider et al., 2017).

\subsection{Econometric Analysis}

\subsubsection{Unit root test}

This study employed the linear (Dickey-Fuller and Phillips-Perron) and non-linear (Güriş) unit root tests to examine the stationarity of the series, as shown in Tables 1-3. Using the Dickey-Fuller and Phillips-Perron tests without structural breaks in the series could lead to spurious results. To overcome this problem, the Zivot \& Andrews (2002) method was used to test structural breaks in the time series. The augmented Dickey-Fuller (ADF) stationarity test results explained that all series were stationary at the first difference. According to the results shown in Table 1, the null hypothesis of non-stationarity was rejected for all the series (LEX, LGDP, LM, LINF) at the $1 \%$ and $5 \%$ significance levels.

Table 1. Augmented Dickey-Fuller (ADF) stationarity test.

\begin{tabular}{|c|c|c|c|c|c|}
\hline \multicolumn{4}{|c|}{ UNIT ROOT TEST RESULTS (ADF) } & & \\
\hline \multicolumn{6}{|c|}{ Null hypothesis: The variable has a unit root } \\
\hline & At Level & & & & \\
\hline & & $\mathbf{L M}$ & LEX & LGDP & LINF \\
\hline \multirow[t]{3}{*}{ With Constant } & T-statistic & 1.0875 & 2.4801 & 0.2348 & -2.3446 \\
\hline & Prob. & 0.9970 & 1.0000 & 0.9726 & 0.1619 \\
\hline & & no & no & no & no \\
\hline \multirow[t]{3}{*}{ With Constant \& Trend } & T-statistic & -1.0865 & 0.3819 & -1.5582 & -2.3957 \\
\hline & Prob. & 0.9223 & 0.9986 & 0.7973 & 0.3779 \\
\hline & & no & no & no & no \\
\hline \multirow[t]{5}{*}{ Without Constant \& Trend } & T-statistic & 2.6270 & 3.0535 & 1.7447 & -1.4692 \\
\hline & Prob. & 0.9976 & 0.9992 & 0.9794 & 0.1312 \\
\hline & & no & no & no & no \\
\hline & At First I & fference & & & \\
\hline & & $\mathrm{d}(\mathrm{LM})$ & $\mathrm{d}(\mathrm{LEX})$ & $\mathrm{d}(\mathrm{LGDP})$ & $\mathrm{d}(\mathrm{LINF})$ \\
\hline \multirow[t]{3}{*}{ With Constant } & T-statistic & -5.3667 & -2.7218 & -6.3842 & -10.1840 \\
\hline & Prob. & 0.0000 & 0.0772 & 0.0000 & 0.0000 \\
\hline & & $* * *$ & * & ***** & ***** \\
\hline \multirow[t]{3}{*}{ With Constant \& Trend } & T-statistic & -5.4883 & -4.1419 & -6.4311 & -10.0829 \\
\hline & Prob. & 0.0002 & 0.0102 & 0.0000 & 0.0000 \\
\hline & & ***** & *** & ***** & ***** \\
\hline \multirow[t]{3}{*}{ Without Constant \& Trend } & T-statistic & -5.0530 & -2.2440 & -6.0882 & -10.2497 \\
\hline & Prob. & 0.0000 & 0.0253 & 0.0000 & 0.0000 \\
\hline & & **** & *** & ***** & ***** \\
\hline
\end{tabular}


The Phillips-Perron (PP) stationarity test results, shown in Table 2 , revealed that all series were stationary at the first difference. This indicates that the null hypothesis of non-stationarity was rejected for all the variables at the $1 \%$ significance level.

Table 2. Phillips-Perron (PP) stationarity test

\begin{tabular}{|c|c|c|c|c|c|c|}
\hline \multicolumn{7}{|c|}{ UNIT ROOT TEST RESULTS (PP) } \\
\hline \multicolumn{7}{|c|}{ Null hypothesis: the variable has a unit root } \\
\hline & At Level & & & & & \\
\hline & & LM & LEX & LGDP & LINF & \\
\hline \multirow[t]{3}{*}{ With Constant } & T-statistic & 0.7956 & 4.0350 & 0.2348 & -2.2999 & \\
\hline & Prob. & 0.9932 & 1.0000 & 0.9726 & 0.1755 & \\
\hline & & no & no & no & no & \\
\hline \multirow[t]{3}{*}{ With Constant \& Trend } & T-statistic & -0.6774 & 1.5832 & -1.6054 & -2.4094 & \\
\hline & Prob. & 0.9699 & 1.0000 & 0.7788 & 0.3711 & \\
\hline & & no & no & no & no & \\
\hline \multirow{3}{*}{ Without Constant \& Trend } & T-statistic & 2.2659 & 5.1094 & 1.6517 & -1.3228 & \\
\hline & Prob. & 0.9939 & 1.0000 & 0.9748 & 0.1700 & \\
\hline & & no & no & no & no & \\
\hline \multicolumn{7}{|l|}{ At First Difference } \\
\hline & & $\mathrm{d}(\mathrm{LM})$ & $\mathrm{d}(\mathrm{LEX})$ & $\mathrm{d}(\mathrm{LGDP})$ & $\mathrm{d}(\mathrm{LINF})$ & \\
\hline \multirow[t]{3}{*}{ With Constant } & T-statistic & -5.3783 & -5.1938 & -6.3842 & -9.9749 & \\
\hline & Prob. & 0.0000 & 0.0001 & 0.0000 & 0.0000 & \\
\hline & & $* * *$ & $* * *$ & $* * *$ & $* * *$ & \\
\hline \multirow[t]{3}{*}{ With Constant \& Trend } & T-statistic & -5.4512 & -6.1720 & -6.3881 & -9.8807 & \\
\hline & Prob. & 0.0002 & 0.0000 & 0.0000 & 0.0000 & \\
\hline & & $* * *$ & **** & $* * *$ & $* * *$ & \\
\hline \multirow[t]{3}{*}{ Without Constant \& Trend } & T-statistic & -5.0484 & -4.7822 & -6.1095 & -10.0345 & \\
\hline & Prob. & 0.0000 & 0.0000 & 0.0000 & 0.0000 & \\
\hline & & **** & ***** & ***** & ***** & \\
\hline
\end{tabular}

Notes: $\left({ }^{*}\right)$ Significant at $10 \% ;(* *)$ Significant at $5 \% ;(* * *)$ Significant at $1 \%$. no means that the series were non- stationary at level.

The Güriş (2019) non-linear unit root test results, shown in Table 3, explain that the calculated values are higher than critical or tabular values at the $5 \%$ and $10 \%$ significance levels. Therefore, the series were non-linear and stationary.

Table 3. Güriș non-linear unit root test.

\begin{tabular}{l|c}
\hline Variable & Test Stat. \\
\hline LM & 11.91 \\
\hline LEX & 16.31 \\
\hline LGDP & 10.62 \\
\hline LINF & 11.55 \\
\hline Critical Values k=2 \\
\hline $1 \%$ & 16.06 \\
\hline $5 \%$ & 11.6 \\
\hline $10 \%$ & 9.64 \\
\hline
\end{tabular}

The Zivot \& Andrews (2002) unit root test was used to test the structural breaks in the series.

Table 4. Zivot \& Andrews (1992) unit root test.

\begin{tabular}{c|c|c|c}
\hline Variables & Break in & T-statistic (Prob) & Breakpoint \\
\hline LM & Trend & $-2.378068(0.0088)$ & 1997 \\
\hline LEX & Trend & $-2.508351(0.0041)$ & 2009 \\
\hline LGDP & Intercept & $-3.636672(0.0043)$ & 2002 \\
\hline LINF & Trend & $-2.696781(0.02312)$ & 2004 \\
\hline
\end{tabular}


Table 4 demonstrates the stationary of series with different break points. The dependent variable had a structural breakpoint in 1997. A dummy variable will be added to the model to show the structural transformation effect of the dependent variable.

\subsubsection{Non-linear ARDL Approach (NARDL)}

The NARDL approach is an advanced version of the linear ARDL approach and was developed by Shin, Yu, \& Greenwood-Nimmo (2014) for linear to non-linear cases. The NARDL model separates the asymmetric effects of positive and negative shocks and is used for a small sample size. In addition, this model could not be applied for the second-order integral series (Almosabbeh, 2020; Kassi, Sun, Ding, Rathnayake, \& Assamoi, 2019). This study used the NARDL approach for its ability to examine the asymmetric effect of the independent variable on the dependent variable (the effect of an asymmetric exchange rate fluctuation on money demand).

The NARDL model is specified as follows:

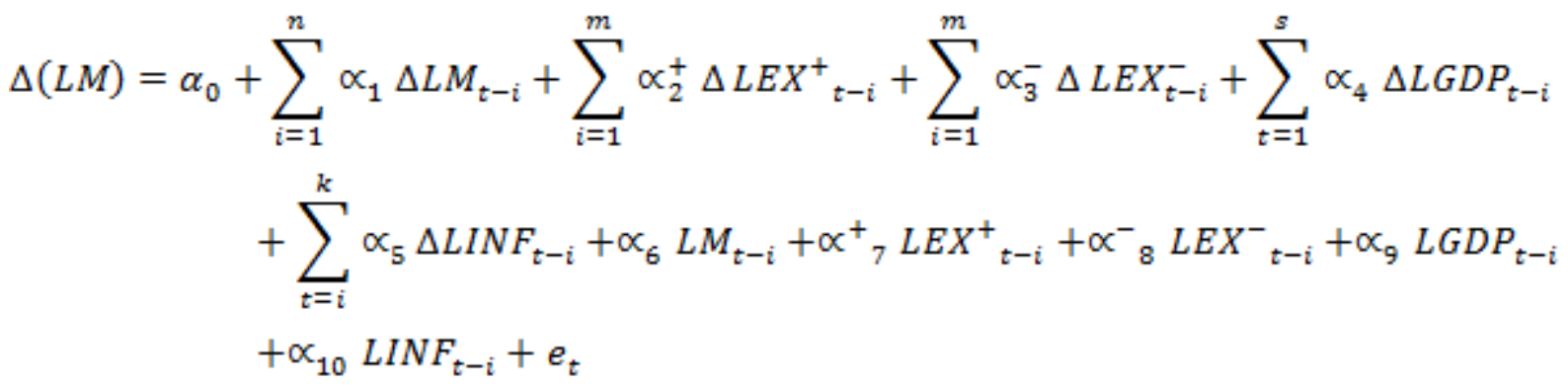

The Wald test was used to discover long-term asymmetry effects based on the null and alternative hypotheses.

$$
\begin{aligned}
& H_{0}: \alpha_{7}^{+}=\alpha_{8}^{-} \\
& H_{1}: \alpha_{7}^{+} \neq \alpha_{8}^{-}
\end{aligned}
$$

Table 5. Estimation of asymmetric NARDL results.

\begin{tabular}{l|c|c|c|c}
\hline & Coefficient & Std. Error & t-Statistic & Prob. \\
\hline C & -3.580551 & 0.738811 & -4.846370 & 0.0000 \\
\hline @TREND & 0.091999 & 0.012963 & 7.096965 & 0.0000 \\
\hline LM(-1)* & -0.869341 & 0.106958 & -8.127844 & 0.0000 \\
\hline LEXX_POS(-1) & 0.346996 & 0.070210 & 4.942264 & 0.0000 \\
\hline LEXX_NEG(-1) & 1.265258 & 0.333963 & 3.788612 & 0.0006 \\
\hline LGDP(-1) & 1.631596 & 0.243943 & 6.688436 & 0.0000 \\
\hline LCPI(-1) & -0.707392 & 0.097246 & -7.274240 & 0.0000 \\
\hline Do9(-1) & -0.321879 & 0.072182 & -4.459263 & 0.0001 \\
\hline D(LM(-1)) & 0.391283 & 0.118050 & 3.314566 & 0.0022 \\
\hline D(LEXX_POS) & 0.147951 & 0.030817 & 4.800985 & 0.0000 \\
\hline D(LEXX_NEG) & 0.420482 & 0.558208 & 0.753272 & 0.4566 \\
\hline D(LGDP) & 0.578924 & 0.121048 & 4.782581 & 0.0000 \\
\hline D(LGDP(-1)) & -1.327066 & 0.190241 & -6.975715 & 0.0000 \\
\hline D(LGDP(-2)) & -0.346418 & 0.141194 & -2.453497 & 0.0196 \\
\hline D(LGDP(-3)) & -0.424880 & 0.099262 & -4.280377 & 0.0002 \\
\hline D(LCPI) & -0.147951 & 0.144667 & -1.022701 & 0.3139 \\
\hline D(LCPI(-1)) & -0.150248 & 0.138599 & -1.084049 & 0.2862 \\
\hline D(LCPI(-2)) & 0.209871 & 0.113645 & 1.846726 & 0.0738 \\
\hline D(Do9) & -0.021742 & 0.076521 & -0.284128 & 0.7781 \\
\hline D(Do9(-1)) & 0.308615 & 0.083008 & 3.717897 & 0.0007 \\
\hline D(D09(-2)) & 0.140658 & 0.080232 & 1.753129 & 0.0889 \\
\hline D(Do9(-3)) & 0.080224 & 0.076993 & 1.041954 & 0.3050 \\
\hline Included observations: 55 & & & \\
\hline F-Bounds Test (K=5) $=13.59031$ & & & \\
\hline & \multicolumn{5}{|l}{}
\end{tabular}




\section{RESULTS}

\subsection{Estimation of Asymmetric NARDL}

The results in Table 5 demonstrate that the value of the ECT $(-1)$ coefficient (-0.766404) was negative and statistically significant. It indicates that any shock would be corrected in more than a year, that is, a year and three months. The dummy variable (D97) coefficient was negative and statistically significant. This referred to the year 1997. It had a structural breakpoint in money demand in Sudan. The time coefficient (Trend) was statistically significant. This demonstrated an increase in the time trend in money demand in Sudan.

\subsection{Long-Term Asymmetry Test}

Table 6 showed that the null hypothesis of the linear relationship was rejected at $1 \%$. Therefore, there was a non-linear relationship between the exchange rate and money demand.

Table 6. Long-term asymmetry test.

\begin{tabular}{c|c|c|c}
\hline \multicolumn{1}{l}{ Wald test } \\
\hline Coefficient & Std. Error & T-Statistics & Prob \\
\hline-0.987577 & 0.191694 & -5.151829 & 0.0000 \\
\hline
\end{tabular}

\subsection{Diagnostic and Stability Analysis}

Table 7 showed that the Breusch-Pagan Lagrange multiplier test (LM test) revealed no problems in terms of serial correlation because the p-value (0.54) was higher than 0.05. The hetero-elasticity test (Arach test) showed no hetero-elasticity; the p-value (0.20) was higher than 0.05. The Ramsey regression equation specification error test (Ramsey reset test) clarified that the model was correctly specified as the p-value (0.1226) was higher than 0.05 . The Jarque-Bera test demonstrated that the residuals were normally distributed since the p-value (0.105) was higher than 0.05 .

Table 7. Diagnostic and stability analysis.

\begin{tabular}{l|c|c}
\hline Statistics & Estimated Value & Prob \\
\hline Breusch-Godfrey Serial Correlation LM Test & 0.376009 & 0.5441 \\
\hline ARCH Test & 1.719559 & 0.1955 \\
\hline Ramsey RESET Test & 0.29643 & 0.8765 \\
\hline Jarque-Bera & 4.495531 & 0.105635 \\
\hline
\end{tabular}

\subsection{Stability Analysis}

The CUSUM and the CUCUM of square tests indicated the stability of the estimated coefficients because the plot of CUSUM statistic fell within the critical bounds of 5\%, illustrated in Figure 1.
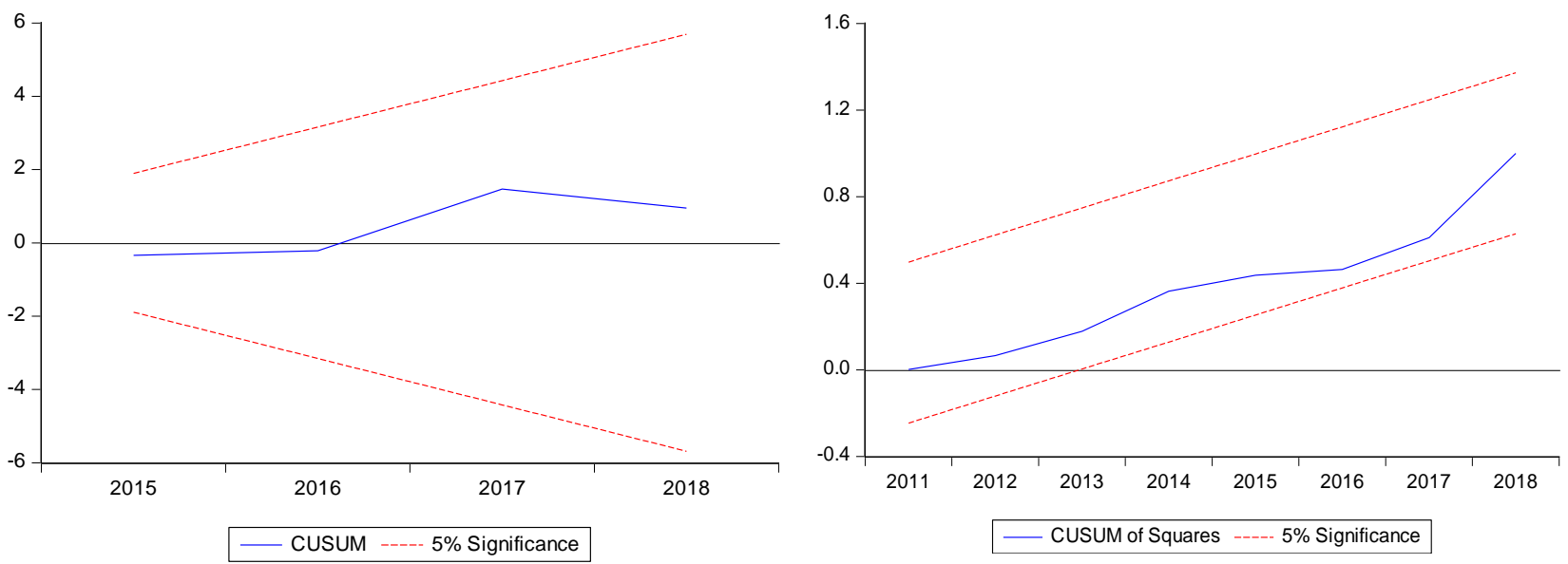

Figure-1. The stability of the estimated coefficients. 


\subsection{Estimation of Long-term Coefficients}

Table 8 showed that the effect of the exchange rate fluctuations on money demand was asymmetric. The coefficient of LEX_POS was statistically significant. Subsequently, in the long term, a 1\% increase in the LEX_POS would lead to a $0.399 \%$ increase in demand for Sudanese pounds. This result implies that the value of foreign assets in Sudanese pounds increases with an appreciation of US dollars. Thus, people sell foreign assets and currency to make profits, resulting in an increase in the demand for the Sudanese pound. However, Sudanese society has a tendency towards imported commodities, and if the value of the Sudanese pound depreciates, then individuals need more Sudanese pounds to purchase commodities, and thus, demand for the Sudanese pound will rise. This finding supports the previous findings of Haider et al. (2017); Mahmood \& Alkhateeb (2018); Bahmani-Oskooee \& Baek (2017). It contradicts the findings of Bahmani-Oskooee \& Baek (2016); Leong et al. (2018). The coefficient of LEX_NEG was statistically significant. In the long term, a 1\% increase in the LEX_NEG would lead to a $1.46 \%$ increase in money demand. This supports the previous findings of Bahmani-Oskooee \& Baek (2017). It contradicts the findings of Haider et al. (2017); Mahmood \& Alkhateeb (2018). The negative effect of the exchange rate fluctuation was greater than the positive effect, indicating that the depreciation of the Sudanese pound has a faster effect because the Sudanese economy did not have a production base. These results indicate that in the long term, exchange rate changes have an asymmetric impact on money demand in Sudan. The elasticity coefficient of GDP was positive and significant at the $1 \%$ level; the elasticity at 1.88 was higher than 1 , which indicated that the transactionary demand for money was large. This outcome supports the previous findings of Leong et al. (2018); Haider et al. (2017); Bahmani-Oskooee \& Baek (2017); Mahmood \& Alkhateeb (2018); Bahmani-Oskooee \& Baek (2016); Suliman \& Dafaalla (2011). The elasticity coefficient of LINF was statistically significant. A $1 \%$ increase in inflation would lead to $0.81 \%$ increase in money demand. This meant that an increase in inflation led to a higher opportunity cost of maintaining the Sudanese pound. Therefore, people preferred foreign assets. This finding supports the findings of Haider et al. (2017); Mahmood \& Alkhateeb (2018); Bahmani-Oskooee \& Baek (2016); Bahmani-Oskooee \& Baek (2017) and Suliman \& Dafaalla (2011).

Table 8. Estimation of long-term coefficients.

\begin{tabular}{c|c|c|c|c}
\hline Variable & Coefficient & Std. Error & T-statistic & P-value \\
\hline LEX_POS & 0.399148 & 0.086372 & 4.621264 & 0.0001 \\
\hline LEX_NEG & 1.455422 & 0.415048 & 3.506632 & 0.0013 \\
\hline LGDP & 1.876820 & 0.241500 & 7.771505 & 0.0000 \\
\hline LINF & -0.813711 & 0.100751 & -8.076441 & 0.0000 \\
\hline D09 & -0.370256 & 0.073946 & -5.007121 & 0.0000 \\
\hline EC = LM - (0.3991*LEXX_POS + 1.4554*LEXX_NEG + 1.8768*LGDP -0.8137*LCPI -0.3703*D09)
\end{tabular}

\subsection{Estimation of Short-Term Coefficients}

Table 9 shows that the coefficient ECT $(-1)$ had a negative and statistically significant value. This indicates that any shock would be corrected more than a year later, that is, a year and three months. The elasticity coefficient of LGDP in the short term was positive and significant. A $1 \%$ increase in the LGDP would increase the transactionary demand for money by $0.34 \%$, implying that the demand was inelastic in the short term. This supports the findings of Haider et al. (2017); Mahmood \& Alkhateeb (2018); Bahmani-Oskooee \& Baek (2016); Bahmani-Oskooee \& Baek (2017) and Suliman \& Dafaalla (2011). The elasticity coefficient of LINF was negative and statistically significant in the short term. A $1 \%$ increase in the LINF would decrease money demand by $0.39 \%$. This effect occurred in the short term, and inflation increase would lead to a higher opportunity cost of holding money. This supports the findings of Haider et al. (2017); Mahmood \& Alkhateeb (2018); Bahmani-Oskooee \& Baek (2016); Bahmani-Oskooee \& Baek (2017) and Suliman \& Dafaalla (2011). The coefficient of LEX_POS was statistically significant. In the short term, a 1\% increase in the LEX_POS would lead to a 0.136\% increase in money 
demand. These results support the findings of Bahmani-Oskooee \& Baek (2017); it contradicts the findings of Haider et al. (2017); Bahmani-Oskooee \& Baek (2016); Mahmood \& Alkhateeb (2018). The coefficient of LEX_NEG was negative and statistically insignificant. This result indicates that in the short term, exchange rate changes have an asymmetric impact on money demand in Sudan.

Table 9. Estimation of short-term coefficients.

\begin{tabular}{l|c|c|c|c}
\hline & Coefficient & Std. Error & T-statistic & Prob. \\
\hline C & -1.483974 & 0.182969 & -8.110536 & 0.0000 \\
\hline @TREND & 0.094964 & 0.010681 & 8.890619 & 0.0000 \\
\hline D(LM(-1)) & -0.423996 & 0.085137 & -4.980143 & 0.0000 \\
\hline D(LEXX_POS) & 0.135951 & 0.022573 & 6.022701 & 0.0000 \\
\hline D(LEXX_POS(-1)) & 0.083899 & 0.041964 & 1.999300 & 0.0547 \\
\hline D(LEXX_NEG) & -1.226814 & 0.654285 & -1.875046 & 0.0706 \\
\hline D(LEXX_NEG(-1)) & 1.658257 & 0.990636 & 1.673932 & 0.1045 \\
\hline D(LEXX_NEG(-2)) & -3.396102 & 1.122053 & -3.026686 & 0.0050 \\
\hline D(LEXX_NEG(-3)) & 1.607096 & 0.984891 & 1.631750 & 0.1132 \\
\hline D(LEXX_NEG(-4)) & -2.364621 & 0.685347 & -3.450256 & 0.0017 \\
\hline D(LGDP) & 0.341711 & 0.077802 & 4.392040 & 0.0001 \\
\hline D(LGDP(-1)) & -0.995803 & 0.124232 & -8.015690 & 0.0000 \\
\hline D(LGDP(-2)) & -0.061043 & 0.109873 & -0.555584 & 0.5826 \\
\hline D(LGDP(-3)) & -0.304864 & 0.089465 & -3.407651 & 0.0019 \\
\hline D(LINF) & -0.388219 & 0.105214 & -3.689799 & 0.0009 \\
\hline D(LINF(-1)) & -0.617482 & 0.109787 & -5.624344 & 0.0000 \\
\hline D(D97) & -0.138926 & 0.082059 & -1.693008 & 0.1008 \\
\hline CointEq(-1)* & -0.766404 & 0.086425 & -8.867820 & 0.0000 \\
\hline
\end{tabular}

\section{CONCLUSIONS AND POLICY IMPLICATIONS}

This study examined the asymmetric impact of exchange rate fluctuations on money demand in Sudan from 1960 to 2018. The study is different from previous studies focusing on Sudan because it employed the NARDL model to separate the asymmetric effects of positive and negative exchange rate shocks on money demand. The augmented Dickey-Fuller (ADF) test, the Phillips-Perron unit root test, the non-linear unit root test and the Güriş unit root test were used to examine stationarity or non-stationarity of the variables. The results revealed that all variables were stationary at the first difference. The Zivot \& Andrews (2002) unit root test was used to test the structural breaks in the series. The results revealed that the dependent variable had a structural breakpoint in 1997. Therefore, a dummy variable was added to the model to show the structural transformation effect on the dependent variable. The results showed that a positive effect in the exchange rate in the short and long terms increased money demand, demonstrating that an appreciation of the Sudanese pound leads to an increase in money demand. A negative effect in exchange rate in the short term did not have any effect on money demand, but a negative effect in the long term decreased money demand. In the long term, the negative effect in the exchange rate was greater than the positive effect, indicating that depreciation of the Sudanese pound had a faster effect. The difference between the positive and negative effects related to the exchange rate indicated its asymmetric effect on money demand in Sudan. Accordingly, this demonstrates that the Sudanese economy did not have the production capacity to meet domestic demand. Thus, the satisfaction of domestic consumption was dependent on imports, which increased domestic product and money demands (Elhassan, 2020). Due to the increase in money demand and insufficient liquidity, the government injected more money into the economy. The positive effect of increased real domestic production put pressure on money demand from consumer spending. This increased the transactional demand for money, which represents the largest component of money demand in Sudan. On the other hand, inflation had a negative effect on money demand due to the eroding purchasing power of the pound. Moreover, the dummy variable had a negative effect on money demand, and this deteriorated cash operations thus discouraging the monetary policy towards increasing real production. 


\subsection{Recommendations}

The findings of this study indicate that the exchange rate fluctuations should be within the ambit of monetary policy in Sudan, and decision makers should adopt policies that can achieve exchange rate stability.

To achieve stability in the target exchange rate, a stable political and economic climate must be created to encourage new investments that reduce imports and increase exports. Stimulating remittances from expatriates through the formal banking system can be used as a tool to achieve this stability.

In addition, an industrial production base should be established to reduce the reliance on imports. Encouraging high quality local production to compete with global markets must be accomplished through incentives. An industrial production base in Sudan can be established that leads to an increase in production in response to local consumer demand; the availability of local commodities achieves commodity security and thus reduces demand for imports.

\subsection{Limitations}

There are a few limitations to this study. First, the study was limited to the period between 1960 and 2018 due to the lack of data for 2019 and 2020. Second, this study revolves around the transactional demand for money in an economy. However, money has other types of demands and their effects on the exchange rate could have profound implications for the economy.

Funding: This study received no specific financial support.

Competing Interests: The author declares that there are no conflicts of interests regarding the publication of this paper.

\section{REFERENCES}

Almosabbeh, I. A. (2020). Is the relationship between government spending and private consumption in Egypt symmetric? Margin, 14(3), 285-308. Available at: https://doi.org/10.1177/0973801020920096.

Alsamara, M., \& Mrabet, Z. (2019). Asymmetric impacts of foreign exchange rate on the demand for money in Turkey: New evidence from nonlinear ARDL. IEEP, 16(2), 335-356. Available at: https://doi.org/10.1007/s10368-0180421-y.

Arabi, K. A. M. (2012). Estimation of exchange rate volatility via GARCH model case study Sudan (1978-2009). International Journal of Economics and Finance, 4.(11), 183-192. Available at: https://doi.org/10.5539/ijef.v4n 11 p183.

Arango, S., \& Nadiri, M. I. (1981). Demand for money in open economies. Journal of Monetary Economics, 7(1), 69-83.

Aworinde, O. B., \& Akintoye, I. R. (2019). Do exchange rate changes have symmetric or asymmetric effects on money demand in Nigeria? AFJ, 21(1), 50-66. Available at: https://doi.org/10.10520/EJC-16fb 1eb3f5.

Bahmani-Oskooee, M., \& Pourheydarian, M. (1990). Exchange rate sensitivity of demand for money and effectiveness of fiscal and monetary policies. Applied Economics, 22(7), 917-925. Available at: https://doi.org/10.1080/00036849000000029.

Bahmani-Oskooee, M., \& Malixi, M. (1991). Exchange rate sensitivity of the demand for money in developing countries. Appl Econ, 23(8), 1377-1384.

Bahmani-Oskooee, M., Xi, D., \& Wang, Y. (2012). Economic and monetary uncertainty and the demand for money in China. Chinese Economy, 45(6), 26-37.

Bahmani-Oskooee, M., \& Baek, J. (2016). Global financial crisis of 2008, asymmetric effects of exchange rate changes, and stability of the demand for money in Japan. Journal of Reviews on Global Economics, 5, 273-280. Available at: https://doi.org/10.6000/1929-7092.2016.05.23.

Bahmani-Oskooee, M., \& Gelan, A. (2019). Asymmetric effects of exchange rate changes on the demand for money in Africa. Appl Econ, 51(31), 3365-3375. Available at: https://doi.org/10.1080/00036846.2019.1578854. 
Bahmani-Oskooee, M., Xi, D., \& Bahmani, S. (2019). More evidence on the asymmetric effects of exchange rate changes on the demand for money: evidence from Asian. Applied Economics Letters, 26(6), 485-495. Available at: https://doi.org/10.1080/13504851.2018.1486979.

Bahmani-Oskooee, M., \& Baek, J. (2017). Do exchange rate changes have symmetric or asymmetric effects on the demand for money in Korea? Review of Economic Analysis, 9(2), 155-168.

Bhatta, S. R. (2013). Stability of money demand function in Nepal. Banking Journal, 3(1), 1-27.

CBS. (2019). The Central Bank of Sudan (CBS). Retrieved from: https://cbos.gov.sd/ar/periodicalspublications?field_publication_type_tid_i18n=46. [Accessed 16/1/2021].

Domowitz, I., \& Elbadawi, I. (1987). An error-correction approach to money demand: The case of Sudan. Journal of Development Economics, 26(2), 257-275. Available at: https://doi.org/10.1016/0304-3878(87)90029-0.

Ebaidalla, E. M. (2014). Real exchange rate misalignment and economic performance in Sudan. African Review of Economics and Finance, 6(2), 115-140.

Ebaidalla, E. M. (2016). Understanding the sources of exchange rate fluctuation in Sudan. Eastern Africa Social Science Research Review, 32(1), 21-40.

Elhassan, T. G. E. (2020). The asymmetric impact of trade openness on inflation in Sudan. Asian Economic and Financial Review, 1O(12), 1396-1409. Available at: https://doi.org/10.18488/journal.aefr.2020.1012.1396.1409.

Güris, B. (2019). A new nonlinear unit root test with Fourier function. Communications in Statistics - Simulation and Computation, 48(10), 3056-3062. Available at: https://doi.org/10.1080/03610918.2018.1473591.

Haider, S., Ganaie, A. A., \& Kamaiah, B. (2017). Asymmetric exchange rate effect on money demand under open economy in case of India. Economics Bulletin, 37(1), 168-179.

Harb, N. (2004). Money demand function: A heterogeneous panel application. Applied Economics Letters, 11(9), $551-555$. Available at: https://doi.org/10.1080/1350485042000225739.

Karfakis, C. I. (1991). Monetary policy and the velocity of money in Greece: A cointegration approach. Applied Financial Economics, 1(3), 123-127.

Kassi, D. F., Sun, G., Ding, N., Rathnayake, D. N., \& Assamoi, G. R. (2019). Asymmetry in exchange rate pass-through to consumer prices: Evidence from emerging and developing Asian countries. Economic Analysis and Policy, 62, 357372. Available at: https://doi.org/10.1016/j.eap.2018.09.013.

Leong, C.-M., Puah, C.-H., \& Liew, V. K.-S. (2018). The impact of Divisia money on monetary model of exchange rate in Indonesia. Economics E Sociology, 11(2), 52-63. Available at: https://doi.org/10.14254/2071-789X.2018/11-2/4.

Leong, C.-M., Puah, C.-H., Lau, E., \& Shazali, A. M. (2019). Asymmetric effects of exchange rate changes on the demand for divisia money in Malaysia. Journal of International Studies, 12(4), 52-62. Available at: https://doi.org/10.14254/2071-8330.2019/12-4/4.

Mahmood, H., \& Alkhateeb, T. T. Y. (2018). Asymmetrical effects of real exchange rate on the money demand in Saudi Arabia: A non-linear ARDL approach. PloS one, 13(11), e0207598. Available at: https://doi.org/10.1371/journal.pone.0207598.

Marquez, J. (1987). Money demand in open economies: A currency substitution model for Venezuela. Journal of International Money and Finance, 6(2), 167-178.

Mundell, R. A. (1963). Capital mobility and stabilization policy under fixed and flexible exchange rates. The Canadian Journal of Economics and Political Science/Revue canadienne d'Economique et de Science politique, 29(4), 475-485.

Nwude, E. C., Offor, K. O., \& Offor, O. K. (2018). Determinants and stability of money demand in Nigeria. International Journal of Economics and Financial Issues, 8(3), 340-353.

Nyumuah, F. S. (2018). The impacts of interest rate and exchange rate volatilities on the demand for money in developing economies. International Journal of Economics and Finance, 10(3), 56-69. Available at: https://doi.org/10.5539/ijef.v10n3p56. 
Shin, Y., Yu, B., \& Greenwood-Nimmo, M. (2014). Modelling asymmetric cointegration and dynamic multipliers in a nonlinear ARDL framework. In Festschrift in honor of Peter Schmidt (pp. 281-314). New York: Springer.

Suliman, S. Z., \& Dafaalla, H. A. (2011). An econometric analysis of money demand function in Sudan, 1960 to 2010. JEIF, $3(16)$.

Zivot, E., \& Andrews, D. W. K. (2002). Further evidence on the great crash, the oil-price shock, and the unit-root hypothesis. Journal of Business \& Economic Statistics, $20(1)$, 25-44.

Views and opinions expressed in this article are the views and opinions of the author(s), Asian Economic and Financial Review shall not be responsible or answerable for any loss, damage or liability etc. caused in relation to/arising out of the use of the content. 